a debate Patrimonio, terrorismo y desastres naturales ¿Cómo prevenir y abordar los enormes daños al patrimonio cultural mundial?

| coordinan Francisco Javier López Morales, Francisco Vidargas

\title{
El patrimonio cultural no es eterno
}

\author{
Antonio Bellido Blanco | conservador de museos de la Junta de Castilla y León
}

URL de la contribución <www.iaph.es/revistaph/index.php/revistaph/article/view/4100>

La preocupación actual por el patrimonio cultural carece de parangón en la historia de la humanidad. Cada pérdida de un bien cultural parece desatar un drama que es fervorosamente seguido por multitud de devotos. Un incendio, una inundación, un robo, un terremoto, una acción de guerra o un acto vandálico despierta numerosos lamentos si afecta a lugares históricos. Eso ha provocado que determinados grupos encuentren una útil vía de propaganda a través de la destrucción intencionada de restos de valor patrimonial.

Sin embargo, ante cualquier siniestro, las personas han de ser la principal prioridad. Puede escandalizarnos la destrucción del patrimonio por parte de grupos armados, arropados en ideologías extremistas, pero esos mismos grupos atacan de forma indiscriminada a civiles y lanzan sus armas contra infraestructuras "inocentes" como hospitales, escuelas o mercados igual que contra museos o monumentos.

Las guerras y los desastres naturales han existido siempre y han afectado a lo que ahora consideramos patrimonio, aunque puede que en su momento no recibieran tal categorización. El pasado nos depara el testimonio de múltiples casos de estos ataques que en absoluto tenían una motivación ideológica. La mayoría de conquistas conllevaba el saqueo de las ciudades y a veces se producían daños no programados por los estrategas militares.

Los godos y otros pueblos "bárbaros", por ejemplo, recorrieron buena parte de los restos del Imperio romano entre los siglos IV y $V$ sometiendo al pillaje muchos lugares sin más afán que recoger la mayor cantidad de riquezas que pudieran encontrar y el pago de un buen rescate podía salvar a una ciudad del saqueo. ¿Cuántas veces fue conquistada Atenas en la época de las ciudades-estado? ¿Cuántas guerras se desarrollaron en Italia durante la Edad Media y el Renacimiento? ¿Qué gran ciudad no ha sufrido ataques devastadores a lo largo de su historia? La ruina ha alcanzado a Roma, Constantinopla, Alejandría, Babilonia, Mosul, Pekín, Manila, Berlín, París, Varsovia, Rotterdam, Madrid...

El tiempo rehace los enclaves de valor identitario, sean del carácter que sean. Roma vio desaparecer muchos de sus monumentos para que su espacio lo ocupasen otros edificios, por más que haya quien pueda cuestionar las reformas de figuras como Augusto, Nerón, Sixto $\checkmark$ o Mussolini. En el caso de Atenas parece que tras la destrucción causada por los persas en el 480 a. de C. sus dirigentes dejaron transcurrir intencionadamente varias décadas antes de que se reconstruyeran los edificios de la Acrópolis.

El pasado tiene un lado oscuro cargado de amenazas. Hay manifestaciones materiales del pasado que es mejor dejar que decaigan. Pocos han pretendido alguna vez la reconstrucción de la Bastilla, en París. Construida en el siglo XIV, fue tomada por los revolucionarios el 14 de julio de 1789 y, por más que tuviera un fuerte valor icónico que aunaba la manifestación del poder despótico real y del triunfo nuevo régimen, se demolió poco después, en cosa de cuatro meses. La acción podría encajar en el perfil de un grupo extremista destruyendo un edificio histórico, ¿no?

Predomina en la actualidad una visión limitada de la extensión del patrimonio que tiende a sobrevalorar determinadas manifestaciones como hitos imprescindibles de la historia mundial. Es como si los occidentales nos hubiésemos adjudicado el papel de jueces del mundo también en temas de conservación patrimonial. Las numerosas páginas reunidas por David Lowenthal en The past is a Foreign Country constituyen una buena muestra de la relevancia que los occidentales dan al pasado y a su valor para justificar el presente. 
a debate Patrimonio, terrorismo y desastres naturales ¿Cómo prevenir y abordar los enormes daños al patrimonio cultural mundial?

| coordinan Francisco Javier López Morales, Francisco Vidargas

La preocupación por lograr la eternidad parece haber llegado al patrimonio cultural y se lucha por conservar cuantas manifestaciones caen bajo el ojo de administraciones y mecenas. No es fácil llegar a todas partes pero, si un elemento patrimonial es destruido de forma intencionada, se produce un refuerzo en la voluntad conservadora. Algunos han olvidado que el tiempo es inexorable y que multitud de obras de arte se pierden. Afortunadamente, habría que añadir, puesto que no tendríamos dónde guardarlas. De pocos artistas se conservan tantas obras como para estar presentes en todos los museos y colecciones importantes e incluso tener varias instituciones en torno a su figura, como es el caso de Picasso, con museos monográficos en París, Barcelona, Málaga, Buitrago de Lozoya, La Coruña y Antibes. Más dolorosa y menos considerada puede ser la pérdida del patrimonio etnológico de las áreas rurales, en progresión ininterrumpida desde hace décadas.

Todo terminará desapareciendo, al menos físicamente. Prevenir la destrucción del patrimonio cultural resulta muy loable y conveniente, pero nada es eterno y la reconstrucción no tiene por qué ser la mejor solución.

Cuando una iglesia gótica, por ejemplo, se convierte en discoteca ¿pierde su valor patrimonial o conserva su carácter representativo para una comunidad? Seguramente mantenga ambos, aunque habrá quien vea en esta transformación una pérdida de relevancia histórica y la reducción a la condición de mero escenario. ¿No ocurre también eso con muchas reconstrucciones?

En culturas distintas a la nuestra la conservación de los elementos de identidad se confían principalmente a la memoria, a gestos y a rituales, no a edificios, coronas, espadas o cálices. En ocasiones se opta por dejar que sean las ruinas las que transmitan una idea, sin necesidad de recuperar lo que se haya perdido. Ahí está la cúpula Genbaku de Hiroshima, conservada en su devastación y convertida en símbolo de la paz.

No faltan monumentos para los que, ya cuando nacen, es fácil prever su futura desaparición. Por todo el mundo

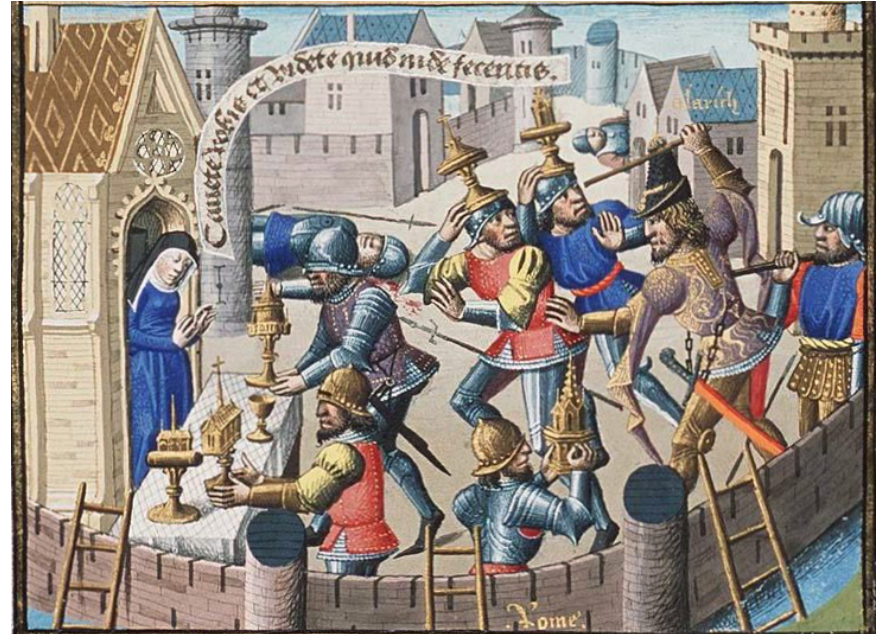

Miniatura Saqueo de Roma por Alarico, tomada del manuscrito de la obra de San Agustín, La Cité de Dieu (vol.l). Realizada en París por el Maestro François hacia 1475

se encuentran estatuas de dictadores que estos se afanan en multiplicar hasta el agobio cuando controlan el poder y tras su caída son destruidas con urgencia. Ernesto Cardenal lo plasmó en uno de sus poemas cuando escribió "No es que yo crea que el pueblo me erigió esta estatua (...) / Ni tampoco que pretenda pasar con ella a la posteridad / porque yo sé que el pueblo la derribará algún día". El caso del Parque Memento de Budapest, una concentración de estatuas que reflejaban la imagen de la dictadura comunista en Hungría, resulta excepcional.

Existen tiempos y lugares en los que la identidad no reside más que en los mitos, las creencias y los relatos, pero también en sus cosechas y el ganado y en sus vajillas y en comportamientos colaborativos. Y cuando una de sus gentes moría era enterrada con sus principales pertenencias, que desaparecían del mundo de los vivos para siempre. Un último elemento de reflexión: el pasado está más allá de lo material, que a veces se aleja de la identidad y se transforma en reclamo turismo. 